\title{
Exploring Improvements of Post-Acquisitions Corporate Performance in Industrial Sector in the Egyptian Stock Market
}

\author{
Ahmed Wael Abdelrahman ${ }^{1}$, Khairy Elgiziry ${ }^{2}$ \\ ${ }^{1}$ Tamkeen Capital Ltd, Cairo, Egypt \\ ${ }^{2}$ Finance, Cairo University, Cairo, Egypt
}

Email address:

awael777@gmail.com (A. W. Abdelrahman)

\section{To cite this article:}

Ahmed Wael Abdelrahman, Khairy Elgiziry. Exploring Improvements of Post-Acquisitions Corporate Performance in Industrial Sector in the Egyptian Stock Market. Journal of Finance and Accounting. Vol. 7, No. 3, 2019, pp. 60-75. doi: 10.11648/j.jfa.20190703.11

Received: April 27, 2019; Accepted: June 4, 2019; Published: June 26, 2019

\begin{abstract}
The purpose of this study is to examine the impact of Egyptians Acquisitions on the post-performance of the acquired companies from the period of 2003 to 2015 by the use of event study methodology. This is done by studying the financial post-performance (includes: liquidity, activity, profitability and capital structure ratios) of a sample consists of 17 companies from the industrial sector as dependent variables, and comparing their results with the pre-performance and the acquisition event as an independent variable. By using a non-parametric Mann-Whitney-Test that can replace the unpaired ttest in the case of small samples, in addition to the factor analysis. The Study tests the significant difference between performance of the acquired companies before and after the acquisition. Empirical results for the whole sample showed a negative significant difference between both the profitability and the capital structure performance of the acquired companies before and after the acquisition. On the other hand, it showed an insignificant difference between both the liquidity and the activity performance of the acquired companies before and after the acquisition. Studying the sub-industrial sectors shows that the Industry Sector has an impact on the performance of the acquired companies and that appears in The Basic Resources and Utilities Sub-sector liquidity, profitability and capital structure performance and has no impact on financial activity performance. For the Construction and Materials Sub-sector there is no impact on the liquidity, profitability and financial activity performance. However, there is a significant impact on the capital structure. For the Personal and Household Products Sub-sector, there is a significant impact on profitability performance, and there is no impact on liquidity, financial activity, and capital structure performance. For the Food, Beverages and Pharmaceutical Sub-sector there is no impact on the liquidity, profitability and financial activity performance and there is a significant impact on capital structure performance. By studying the impact of the Capital Issued on the post-performance of the acquired companies, the researcher showed that there is an impact on the capital structure performance for the acquired companies below $50 \mathrm{M}$ and on profitability performance above 50 $\mathrm{M}$ issued capital. On the other hand, there is no impact on the other performance measures for companies above and below 50 $\mathrm{M}$ issued capital. Finally, the study results introduced some useful recommendations for the acquisition events in the Egyptian Market.
\end{abstract}

Keywords: Acquisition, Company Performance, Event Study, Industrial Sector, Egyptian Stock Market

\section{Introduction}

As a result of globalization and liberalization policies in the last two decades starting in 1991, The Egyptian Economy has taken a significant and vital transformation and structural changes. This study aims to fulfill part of the gap in the literature review in the Middle East and North Africa, concerning the analysis of acquisition impact on the performance of the industrial sector. According to Robert et al. (2016) [1] merger and acquisition can be defined as a combination of two or more firms into one new firm or corporation. By identifying well, the way of the combination of the two companies, we could easily differentiate between 
the merger transaction and the acquisition transaction. In merger case usually, a negotiation process is involved between the two companies, while in acquisition case a company buys fully or partially the other one, and in most cases, the target companies are acquired by the acquirers by buying their stocks. Acquisitions activities could be either friendly or hostile. In a friendly acquisition case, the target company is willing to be acquired, while in the fact of hostile acquisition, the target company refusing the deal. Many purposes help in the determination of the merger or acquisition nature. These purposes are, strategic purpose, that make use of the merger or acquisition activity to accomplish specific strategic objectives, speculative purpose, where the target company is being viewed as a commodity by the acquirer, management failure purpose, where sometimes companies being forced to go to the deal because of failures of management, financial necessity purpose, where the companies need to make a takeover for financial necessity reason, and finally, political use, where some political influences are significantly affecting the decision to go to merger and acquisition activities. As Robinson and Zerdin (2013) [2] explained, that the economy of Egypt in 2012 faced a critical situation after the political disturbance that produced a hard decline in foreign investments and foreign currency reserves, in addition to an increase in the deficit of the budget and external and domestic debts. Merger and acquisition transactions showed some improvements that led by both strategic and private equity activities. The Egyptian Region represents a perfect field for Merger and acquisition activities in light of its diversified businesses and economy that have a strategic geographical position and strong demographics. Metwalli and Tang (2003) [3] referred to Merger and Acquisition activities in the Middle East in the 1990s were globalized events that included both firms from the Middle East and firms from other regions including Europe, North America, and Asia. In the period from 1990 to 2000, Israel's Merger and Acquisition activities accounted for thirty-seven percent of the total deals and forty-three percent of the value of target firms in the Middle East. Egypt accounted for sixteen percent of the total deals and eight percent of the value of the transactions. Kuwait and Saudi Arabia also had big volumes of Merger and Acquisition activities. More than fifty percent of the Merger and Acquisition transactions in the region from 1999 to 2000 were done by asset acquisition. Acquisition for majority interest also accounted for about thirty-five of the deals. Acquisition methods in the Middle East are different from the others that used in emerging markets such as Latin America and Southeast Asia. The Merger and Acquisition activity is so large for many countries in the Middle East for the following reasons: (1) The acquiring firms may benefit access to proprietary technology and information; (2) mergers and acquisitions help the firms to involve expand their new and existing products to other markets; and (3) Both the acquiring and the target firms may achieve greater synergy through economies of scale and elimination of duplicating functions and tasks. These benefits of mergers and acquisitions should develop the competitive advantage of firms in the region. Merger and Acquisition Waves as mentioned in Martin's article (2007) [4] changed every 20 years. There is general understating about the timing of the merger waves broad outlines. The economic depressions correlated the First Merger Wave in 1893 and 1903. Within this wave, merger cases were occurring in monopolist firms in their production lines of production, for example, electricity and railroads. The Second Merger Wave was started in 1919, after the first year of the World War I, and in some other researches, it started from the 1920s, around the 1921 economic depression. The second wave mainly took place from 1926 to 1929 and ended before the great depression October 1930, and focusing on the oligopolistic mergers, not monopolistic as the first wave. The Third Merger Wave was starting 1964 to 1965 and ended finally by 1970 or 1971. It took a little time about half a decade mainly concerned with conglomerate cases. The Fourth Merger wave, starting in 1981 and ended early 1989 in U.S. merger activity. Merger cases were characterized by higher stocks prices, the rate of interest and active encouragement of antitrust laws. The Fifth Merger wave started in the early 1990s was attributed with Globalization that is a consequence of technological change and falling trade barriers and finished before September 11th.

\section{Research Problem}

What is the impact of Acquisitions on the post-acquisition performance of the acquired firms? To answer this question, empirical investigation for the impact of acquisition transaction on the financial performance of the industrial listed Egyptian firms have done, by comparing the pre- and post-performance of the acquired firms. Financial performance evaluation will be calculated by using financial ratios before and after the acquisition transaction. These financial ratios will be divided into four main ratios, and each includes some consistent financial analysis ratios, those are liquidity, profitability, activity and capital structure ratios.

\section{Research Objectives}

To examine the following items:

a. The impact of Egyptians Acquisitions on the postperformance of the acquired companies.

b. The impact of industry sub-sector on the postperformance of the acquired companies.

c. The impact of company size on the post-performance of the acquired companies.

\section{Literature Review}

\subsection{Theoretical and Strategic Review}

Hitt \& Pisano (2003) [5] pointed out in their research to the increasing importance of the Cross-border acquisitions strategy that is used by many companies in different regions 
all over the world. Few studies have been directed to this strategy. The Cross-border strategy has some unique characteristics that differ from those of domestic mergers and acquisitions strategy. At the same time, this strategy possesses some attributes that are similar to domestic strategy. The primary objective of the research is to study the importance of Cross-border mergers and acquisitions and to analyze their opportunities, in addition to the threats that may face this strategic action. Companies able to diversify their activities geographically, the easy access to valuable, worthy resources and new knowledge learning are examples from significant opportunities of Cross-border strategy. These opportunities are considered much valuable and have a substantial contribution to the companies' competitive advantages, when compared with domestic mergers and acquisitions, due to the unique institutional and cultural variations that are often found between the companies being involved in Cross-border transactions. On the other hand, the threats that face Cross-border mergers and acquisitions incorporate the institutional and cultural variations, hardly evaluating acquired foreignness companies' assets and liabilities in comparing with domestic strategy. To understand well this phenomenon, more researches are required in the market to explain the factors affecting the deal negotiation and the synergies achieved after the acquisition transaction completion as consolidations and globalization, in addition to analyze the details of identifying potential targets for acquisitions, the process of due diligence, the integration of post-merger, and the ways to create new knowledge and organizational learning. The strategy of cross-border mergers and acquisitions has turned into an important strategy used by companies in the international market. Managers must understand well the Cross-border strategy's opportunities and threats that surround the transaction, and must know well how to raise the percentage of having successful transaction. Chen et al. (2004) [6] applied the concept of perfect Bayesian Equilibrium to study the takeover game equilibrium, and to explain the takeover motivations. The results showed that the hypotheses of private benefits, hubris, and synergy might describe why firms perform the mergers and acquisitions; the primary and essential point between those motives is that how the acquiring firm management expect and assure the strategies and movements of the acquired firm. When the acquiring firm management indefinitely knows that the acquired firm either cooperates or resists, the synergy and hubris hypotheses are supported. But in the case, the management of acquiring firm indefinitely expects that the acquired firm will resist, the hypothesis of private benefits will be supported. The results also showed that, in some situations, the higher management of acquiring firm over confidentiality and the higher private benefits is expected, the higher the probability of the merger and acquisition to be motivated.

\subsection{Factors Influencing Firm Post-Transaction Performance}

Ismail et al. (2011) [7] studied and concluded that there are eight factors affecting merged firm performance after the transaction which are: merger and acquisition types either related or unrelated, cross-border versus domestic merger and acquisition, method of payment (cash or stock), company size, book to market ratio, tender offer versus mergers, macroeconomic factors conditions, and time period of transaction. Managers and investment bankers should be aware of these factors and their effects on the Merger and Acquisition post-performance of the companies being merged or acquired. There are ambiguous results on the literature on the results of mergers and acquisitions on corporate performance as well as factors that might affect these transactions. Previous studies used varieties of measures to examine the impact of Merger and Acquisition on corporate performance, where measures might be accounting based-measures, market based-measures, mixed measures, or qualitative based-measures. Bouwman et al. (2004) [8] drew the attention that literature has confirmed that periods of high market valuations are correlated with high merger activity, that means when stock markets are booming more merger and acquisition transactions are executed compared with the market of depression. The study depended on this correlation between the market valuation and the number of mergers, with much analysis in the impact of market valuation on the merger and acquisition performance. The study found that buying targets during the periods of high valuation stock market shows lower abnormal returns than buying targets in the periods of lower valuations, even when controlling the valuation factor. Three possible reasons for that underperformance of buyers during high stock-market valuations periods: market-timing, overpayment and managerial herding. By more analysis, results showed the under-performance is much correlated with managers herding than market-timing or overpayment. Bradley and Sundaram (2006) [9] tested the performance, strategies and the characteristics of buyers in 12,476 US completed acquisitions transactions during the $90 \mathrm{~s}$. They concluded that acquirers' portfolio outperformed significantly the benchmarks of the market, and that the frequent acquiring firms outperforming infrequent acquiring ones. This noticed outperformance impacts the superiority of the performance of stock price that happens before, and not after the announcements of such acquisitions, and implies the very good performance that creates acquisitions rather than the reverse. Adding to the pre-acquisition run-up of the stock price, in most of the cases, there is an economically and statistically positive significant market reaction to the announcement of the acquisition itself. In addition to that, it was found that acquiring firm size is not the most important factor for the market reaction as a result of acquisition transaction announcement, but, the organizational form of the target firm either public form or non-public form is considered an over power factor that affects the market reaction. Also, the targeted acquired firm size and the medium of exchange are all important factors like the buyers' size. Rani et al. (2014) [10] in their research created a corporate governance index for a sample of companies to 
check whether differences in quality of the level of corporate governance standards influencing the performance of acquiring firms. The study is based on a sample of one hundred fifty-five firms completed mergers and acquisitions transaction. By analyzing the relationship between acquiring firms' corporate governance practices and abnormal returns during event windows around the announcement of Merger and Acquisition and post-Merger and Acquisition acquirers' financial performance. It's concluded that a positive relationship between corporate governance standards and the acquiring firms' financial performance. Harrison et al. (2013) [11] explained from an agency perspective that leverage might have a positive impact on company's performance by increasing pressure on managers to perform well and also by limiting their ability to allocate resources to unproductive uses. Therefore, they may expect the leverage to have a positive impact on the performance of the acquisition. In spite of the risks increase associated with higher leverage, in addition to the other risks come with an acquisition, also force managers to take actions to decrease risk even if doing that will affect the value maximization. High level of debts may also reduce the managerial discretion over resources allocation during the process of acquisition, which may have a negative performance impact. They investigated the leverage impact on the stock performance of post-acquisition and found that performance of the post-acquisition has decreased in leverage brought by the acquired firm and additional leverage has been added to complete the acquisition. This negative performance is aggregated among the buyers who are already financially constrained. Their results are strong to many gains measurement methodologies and to the inclusion of several controls known to expect future gains. Besides, viable investment strategies that suggest market underestimates difficulties that arise from acquisition-related increases in leverage.

\subsection{Financial Performance Analysis}

\subsubsection{Liquidity Analysis}

Al-Hroot (2016) [12] investigated and analyzed the effect of merger transactions on the Industrial Sector in the Jordanian Market. The findings showed that Jordanian Industrial Firms follow the same stream of the world in studying mergers impact. The study has two different insignificant results in financial changes in the post-merger period, liquidity, efficiency, and profitability are improved insignificantly on the other hand leverage ratios are decreased insignificantly. Moctar \& Xiaofang (2014) [13] examined the effect of merger and acquisition transactions on the West African Banks' financial performance. The region of the research covers the most famous African regional and economic community The ECOWAS (Economic Community of West African States). The financial ratio analysis is divided into three groups of variables, liquidity ratios, investment valuation ratios and performance ratios. The case study used two bank groups: the first group consists of banks that have passed merger and acquisition transactions and the second group includes the banks that did not pass merger and acquisition transactions. First by comparing the first group situation pre and post the mergers and also staring analysis for the two groups by using financial ratios regarding performance, liquidity, and investment valuation. The conclusion reflected that liquidity ratios group in merger and acquisition transaction for banks has improved financial performance. Also, it indicated that investment and performance variables declined in the period of merger and acquisition and increased two or three years after. To summarize, in West Africa banks, merger and acquisition transactions have positive significantly impacts on the liquidity group of banks, on the other hand, performance and investment groups have a negative impact in short-term and positive impact in long-term financial performance. Rathinam and Sridharan (2010) [14] examined the Mergers and Acquisitions' impact on the financial efficiency of selected Indian financial institutions. The study mainly concerned with the overall liquidity parameters, profitability parameters, solvency parameters and the overall parameters of efficiency. The conclusion showed a significant change in the shareholders' earnings; a small change in the liquidity position; a significant change in the long-term solvency position of the firms; and an overall significant efficiency change in the banks. It is indicated that the Indian Mergers and Acquisitions have a significant impact on the financial performance of financial institutions and that the acquirer was able to generate value for their companies. Rashid and Naeem (2016) [15] examined the effect of merger transaction empirically on corporate financial performance in Pakistan. Ordinary least squares (OLS) and the empirical Bayesian estimation methods are used for analysis. The results of OLS regression showed that the merger transactions have an insignificant effect on the liquidity, profitability and the company leverage position, however, the estimates before showed that the merger transactions have a negative significant statistically effect on the quick ratio of the merged companies. The study showed that the results of the empirical Bayesian method are consistent with the OLS results.

\subsubsection{Profitability Analysis}

Abdulwahab \& Ganguli, (2017) [16] studied the impact of merger and acquisition transactions that took place in Bahrain Financial and Banking Sector. By using fifteen financial ratios through the Rating Model, CAMEL ( $\mathrm{C}$ for capital adequacy, A for asset quality, $\mathrm{M}$ for management quality, E for earnings quality \& L for liquidity position) to test the significance of the financial change empirically that happens pre and post-transaction. Findings showed that no significant change in the financial performance for both the acquirer and acquired firms, except in one transaction that has a significant improvement. In other words, in Bahrain Banking Sector the financial performance does not get improved after merger and acquisition transactions. Besides, merger and acquisition transactions in Bahrain during the same period have not produced desirable results, at least three years after the merger. Abbas et al. (2014) [17] expressed that organizations worldwide use Merger and 
Acquisition activities to cope with the dynamic business culture. The study aimed to test the financial performance of banking sector in Pakistan after the Merger and Acquisition transactions. The financial performance was measured by major important financial ratios groups, liquidity, profitability, efficiency and Leverage ratios, for the data before and after the Merger and Acquisition transactions. The study showed that there are no positive improvements in the Pakistani banks' financial performance after Merger and Acquisition transaction Jallow et al. (2017) [18] examined the impact of merger and acquisition transactions on firms' financial performance in The United of Kingdom. Mergers and acquisition transactions are considered the independent variable of the study and the dependent variables are the profitability ratios measured by Return on Equity, Return on Assets, Net Profit Margin and Earning per Share. The results showed that profitability ratios indicators are correlated positively to merger and acquisition transactions. Merger \& acquisition transaction has a significant effect on return on Equity, earning per Share, and return on assets, but net profit margin ratio was not affected by merger and acquisition transaction as other profit ratios. Mulwa \& Mwangi (2015) [19] examined the impact of merger and acquisition transactions on the financial performance of the Oil Industry in the Kenyan Economy by conducting financial and statistical analysis for the oil sector in Kenyan industry. Regression analysis was used to measure the financial performance and the independent-dependent variables relationships. The dependent variables were the liquidity, financial leverage, size of the merged/acquired, capital adequacy. It is concluded that oil firms have a bad performance after the acquisition transaction when being compared with the preacquisition period. A negative effect on the financial performance of petroleum firms, but it is not statistically significant. Acquisition transaction has a negative impact on return on assets, but it is not significant. Both firms' size and capital adequacy have negative impacts on return on assets and statistically insignificant. Masud (2015) [20] aimed to explain the financial performance of the target sample units after the merger and acquisition transactions. Profitability measures (return on assets, return on equity and earning per share). After conducting the test, the study showed mixed results, some of the sample units had a positive impact, and others had a negative impact after the acquisition. When talking about the sample as a whole, the results showed significant positive improvements in the long run even there was some decline in the first year after the acquisition transactions. Abdulazeez et al. (2016) [21] examined the effect of merger and acquisition transactions on the financial performance of some selected Nigerian banks by using Return on Equity and Returns on Assets for the selected sample pre and post-acquisition activity. The researchers concluded that merger and acquisition activity had improved the bank 's financial performance that led to more financial efficiency in the Nigerian banking sector. They recommended that Nigerian banks must follow more aggressive acquisition strategies to benefit much from financial efficiency improvements. Dutescu et al. (2013) [22] analyzed the rate of success impact of merger and acquisition activities in Romania in 2007 and by the comparison of audited financial statements of the acquired firms' pre and post-the acquisition and with the aid of three financial ratios: profit margin, receivable collection period and return on equity. In conclusion, two out of the ten companies from the selected sample of the essential cases happened in the Romanian Market that year succeeded, and the other eight deals failed. Reda (2013) [23] examined the effect of mergers and acquisitions on the profitability and efficiency of the banking sector in Egypt by using Data Envelopment Analysis (DEA). The findings showed the reality that there is an improvement in risk management, managerial efficiency and the profitability and intermediation function still not improved. Olson et al (2003) [24] examined the stock long-term operating performance of the mergers for publicly traded holding companies for banks. It is concluded that there are some factors that are considered economically significant for the abnormal stock return of the merged bank's performance over the following three years after the banks mergers which are: post-acquisition changes in the estimated sustainable growth rate prior to the acquisition, the sustainable growth rate itself, and the dividend payout ratio of banks. Ferrer (2012) [25] showed that the business combination of economic advantage could be proved and examined by the ways that the firms need to enlarge their share in the market. It's concluded that a significant negative relationship of the merger transaction and return on equity ratio, that indicates that most merger and acquisition transactions have a bad impact on financial performance of the firms, rather than being a good impact. Also, mergers and acquisitions have an insignificant relationship to the return on total assets ratios, as evidenced by insignificant p-value. Finally, the findings of this study concluded that having mergers and acquisitions has no significant effect on the return on assets ratio in the Philippines firms. Teodora \& Braşoveanu (2016) [26] examined the merger and acquisition impact on firms' financial performance. The study sample was selected from merger and acquisitions, from Romania and Central Europe's firms. It is concluded that most of the independent variables have a direct effect on dependent variables, Juma \& Musimenta (2017) [27] studied the effect of merger and acquisition transaction on the company performance in East Africa Region, by applying event study and calculating the abnormal cumulative returns to analyze and evaluate the performance of merger and acquisition transaction and shareholder wealth, and evaluate company performance. It is concluded that merger and acquisition transactions are associated significantly with company performance. Besides, mergers and acquisitions announcements generate significant abnormal returns to the company's shareholders and domestic merger and acquisition deals have a positive relationship with firm performance. Alhayek (2018) [28] 
identified and analyzed the acquisition impact on acquired firm income statement items, in Irbid Electricity (IDECO) case study. Significant statistically differences in energy purchase cost, energy sales average, other revenues, other operating revenues, earnings per share and operating expenses, pre and post-acquisition. In addition, insignificant differences between the average of other expenses pre and post-acquisition. Badreldin \& Kalhoefer (2009) [29] examined the Egyptian banks' performance that have passed through merger or acquisition transaction. They used the return on equity ratio to examine the degree of banking reforms success in consolidating and strengthening the Egyptian banking sector. The results showed that not all the banks in the sample expressed significant improvements when comparing after merger and acquisition transaction by before the transaction. It is concluded that merger and acquisition transactions have no impact on the banks' profitability in the banking sector of Egypt. A minor positive impact has been noticed on the position of the credit risk. These conclusions do not support the consolidation trend in the banking sector in Egypt. Verma \& Sharma (2014) [30] mentioned the incredible recent growth in India in the Mergers and Acquisitions transactions that played actively in all industrial sectors. This study examined the effect of mergers and acquisitions on the Indian Telecom industry performance, by use of some operating and financial variables pre and post the transaction. It is concluded that Mergers and Acquisitions have some changes on the return on shareholder's funds, that firms showed insignificant improvements in the operating performance and significant underperformance in the financial performance. They confirmed that merger and acquisition transactions do not improve the shareholder's funds of the firms. Sujud \& Hachem (2018) [31] examined the pre- and post-merger impacts on Audi Saradar Group financial performance. It is concluded that return on equity and return on assets are insignificantly improved. There is a significant positive impact on earnings per share. Singh (2013) [32] mentioned to the Indian Mergers \& Acquisitions transactions that have exhibited significant growth as corporate restructuring activity recently and have become an essential economic and financial corporate strategy worldwide. Its concluded that a long-run improvement in financial performance of merging companies especially profitability ratios and that merger and acquisition is considered effective corporate restructuring method, and should become an Indian longterm business strategy of corporates. Lakstutiene et al. (2015) [33] drew attention to a long scientific debate in many countries that is created from the economic results and consequences of corporate acquisitions cases which are executed under different economic conditions and by the use of various business strategies in Lithuania. The study concluded that both economic values added and profitability ratios have been decreased during the shortterm period after the acquisition transaction in most of the cases. However, there is a sort of recovery that can be recorded during the last quarter which can indicate that the acquisition transactions can generate some benefits during the slowdown of the economy.

\subsubsection{Activity Analysis}

Lipeikyte \& Schneider (2015) [34] studied the Baltic States economy where small and medium companies are dominated and expressed new understandings on how mergers and acquisitions impact on small transition economies. Logit regression, ordinary least squares (OLS), and generalized least squares (GLS) were the three models that are used in the study and each model with different independent and dependent variables. The final findings of the study showed that acquired target firms with a high rate of productivity are likely to have major ownership change. Besides, acquired firms experience a high rate of postacquisition productivity when comparing them with nonacquired firms. The acquired firms have no Significant productive results when comparing domestic and foreign acquirers. Singh \& Das (2018) [35] evaluated the effect of merger and acquisition transactions on the Indian Banks' financial performance, by reviewing the merger and acquisition trends in Indian banking sector and then studying the merger and acquisition impact on three leader banks in India. The study used financial parameters like operating profit margin, net profit margin, return on equity, return on capital employed, capital adequacy ratio, dividend per share, earnings per share and others. The conclusion showed that policies and strategies in physical, procedural, and sociocultural contexts are very vital aspects in the post-merger acquisition activity. Adding to previous, the qualitative impacts of the post-merger acquisition activity such as market valuations, accounting reports and key informant descriptions are vital and enormous to Bank performance and capabilities improvement. kenkel et al. (2017) [36] studied and analyzed the twenty-two Oklahoma cooperatives audited financial statements to investigating the impact of mergers in improvement of the financial performance by using five annual financial ratios, which are calculated for each company in addition to the use of paired difference tests to analyze the impact of merger transaction in financial performance improvement. On the contrary with studies previously done, the tests revealed that mergers have been generally successful in increasing efficiency and profitability. The financial performance on average, of surviving companies, has improved the post-merger performance. The small sample size made it hard to generalize that conclusion on the global Oklahoma market. Bayyurt \& Akin, (2014) [37] analyzed the impact of foreign takeovers such as acquisitions on the company stock performance in the Turkish market with the aid of Panel Regression and Data Envelopment Analysis. The researcher showed that foreign acquisition has a significantly positive contribution to the companies' stocks efficiency. This impact is appeared for two years post the acquisition transactions and in the recent years becomes much stronger. Pervan et al. (2014) [38] expressed the enormous increase in the value and importance of 
massive Merger and Acquisition transactions on Croatian firms. The findings clearly showed statistically insignificant changes in target firms' performance before and after Merger and Acquisition transactions. The same findings, that means statistically insignificant changes, were also found even when after acquisition performance of target firms was compared to the peer firms. Finally, the results showed that instead of the growing influence of foreign investors in the Croatian economy, the majority of Merger and Acquisition activity was carried out by Croatian firms. Nelson (1959) [39] concluded that Merger activities have a significant effect on the stock market. By using simple regression, he found that there is a significant relationship. The acquisition of one company by another or the consolidation of many companies into one is an action of investment by the investor initiator or the merger, the same as different types of investment. The investor calculation is used in determining the value of the target firms with the expected returns ability of the merged company is similar to the calculation he did in deciding to initiate a new plant or to get new investment. Gruici et al. (2010) [40] tested the relationship between the merger and acquisition activities and stock prices in The Romanian Stock Market, explained by the Bucharest Exchange Trading indexes (BET) and (BET-C). They concluded that both ways or at least one way of relationships are presented in this market and that happened by examining some merger and acquisition transactions, based on theoretical evidence and empirical studies by using the Granger causality. Liargovas \& Repousis (2011) [41] studied The Greek Market and tested the effect of merger and acquisition transactions on The Banking Sector. They rejected the Efficient Market Hypothesis (EMH) Semi-Strong Form in The Athens Stock Exchange, by using the methodology of the event study. Considerable positive significant cumulative average abnormal returns (CAAR) have been received by shareholders, ten days before the merger or acquisition announcement. Upon the announcement also of diversifying and horizontal bank deals, positive significant CAARs are achieved. The overall study outcomes concluded that the mergers and acquisitions of banks do not generate wealth and have no effect. In addition to the above, there are no improvements in the operating performance after the transaction measured by twenty financial ratios relating to the operating performance of the Greek Banking Sector.

\subsubsection{Capital Structure Analysis}

Pham (2014) [42] tested and analyzed the financial performance using financial ratio analysis of the pre and post-acquisition transactions for the banking sector in the Czech Republic by using a sample of four banks. The five main ratios are Return on Assets, Return on Net Worth, Earning per Share, Debt to Equity and Net Profit Margin. The final result of the study showed that no significant improvements in the financial performance of the selected sample, that means the banks must do much study in order to gain positive gains from the acquisition transactions. Bhutta (2015) [43] showed the effect of merger and acquisition transaction, pre and post the event, on the service sector in Pakistan by analyzing a case study of Pakistan Telecommunication Limited (PTCL). This case study has been divided into two sections. Regression analysis model was used in the first section to discuss the effect of profitability and financial ratios position on the score of bankruptcy. In the second section of the study and by using the time series, the researchers analyzed the pre and postmerger and acquisition financial ratios trends. There is a significant positive effect of profitability and financial position (capital structure) ratios on the score of bankruptcy in section one results. In the second section by using financial ratios, the findings showed a negative effect on that score of bankruptcy after the acquisition, also over time, the financial position of the company remained stable. The final results suggested a decline in company's performance during the time of observation. Ntuli (2017) [44] studied the acquisition case that happened for $56.4 \%$ of the stockholder's equity of ABSA (Amalgamated Bank of South Africa) by Barclays Bank Plc, analyzed and evaluated the financial performance of ABSA after the acquisition transaction by accounting measurements. It is concluded that the Returns on Assets, Equity and Investments Ratios are increasing for ABSA post-acquisition and the Debt to Equity Ratio decreasing. The main conclusion is that ABSA acting better in the post-acquisition than a pre-acquisition period and the share price was increasing. Joash \& Njangiru (2015) [45] showed that the majority of researches have concluded that mergers did not improve the financial performance of firms measured by the earnings and profitability ratios. They examined the merged bank cases that executed in Kenya. It is concluded that the merger and acquisition transaction raised the value of shareholders' equity of merged and acquired Kenyan banks. Besides, most of the merged or acquired banks had a raise in their profitability. Feasibility studies before merger and acquisition transaction must take place to achieve better results. Arlinda et al. (2015) [46] explained that the Indonesian telecommunications (T. Com) business has passed by $100 \%$ market penetration that tends to change the market to be oversaturated. So, merger and acquisition cases are used in the Indonesian telecommunication market to release some pressure of this over-saturation. The Paired T-Test analysis used in the study showed the significant differences in return on assets and market value added to one company, market value added and the Debt to Equity on another company and some other financial ratios, economic value added, market value added, price to book value and price-earnings ratios for two other companies. The impacted variables differences are caused by the post mergers and acquisitions differences duration for each observed firm. Also, there was no change in market share for these five big T.com after merger and acquisition transaction takes place. Larasati et al. (2017) [47] tested the change in financial performance of the company pre and post the acquisition transaction. The audited financial statements and financial reports were used as secondary data. Wilcoxon Signed Ranked Test was used in the data analysis. It is concluded 
that there are insignificant differences between the selected sample companies for the following financial ratios: a decrease in net profit margin, current ratio, price earnings ratio and total asset turnover, an increase in debt to equity ratio pre and post-merger and acquisition transaction on the listing company in the Indonesian Stock Exchange in the research period.

\subsubsection{Impact of Company's Size on Acquisition Success}

Lipeikyte \& Schneider (2015) [34] divided the sample into three sub-samples according to size; large, medium and small, the results showed that firms from short and medium size SMEs are experienced much more improvements and productivity in the stage of pre-acquisition when being compared with the non-acquired firms of similar size. As for large acquired firms, they experienced no change or improvements in the pre-acquisition stage when being cp0ompared with non-acquired firms and no significant productivity improvements in the stage of post-acquisition. Filipovic (2012) [48] mentioned in his study that a large number of merger and acquisition transactions do not result in synergies planned and that merger and acquisition are impacted directly by different variables like strategy, management, corporate culture, structure, company size and others. The researchers tested the effect of a firm's size on the success of the takeover. The definition of takeover success is that the acquired firm has a better performance in the period after the takeover than before the transaction. A sample of forty-three firms acquired in the Republic of Croatia analyzed using statistical tests T-test and Chi-square. It is concluded that there is a significant correlation between the size of the target firm and the size of the acquirer and the success takeover happens when the acquirer is bigger than the target company. Savovic (2016) [49] explored the financial performance of target firms' after the acquisition transaction in The Republic of Serbia, and if the firm size is considered a factor of post-acquisition performance. The sample data is collected from ninety-one managers in ten acquired firms. The analysis concluded that seventy per cent from the sample confirmed an improvement in performance after the acquisition. The performance improvement is achieved mainly through cost reduction. There are significantly statistical differences between small, medium and large firms. Medium firms are the best regarding nonfinancial performance improvements. Large companies are the best regarding financial performance improvements.

\subsubsection{Impact of Sub-sectors on Acquisition Success}

Al-Hroot (2016) [50] checked and analyzed the significance of the financial improvements that have happened post-merger transactions in the Jordanian Industrial Sector in the period from 2000-2014. The effect of merger transactions differed from the industry sector to another. Medical and Pharmaceuticals industries efficiency, market prospect profitability, performance indicators after- merger have significantly improved. On the other hand, post-merger liquidity, and leverage insignificantly declined. The merger has impacted positively on medical industries and pharmaceuticals. In Chemical industries, liquidity, market prospect and profitability performance indicators have improved insignificantly after merger while leverage and efficiency have insignificantly declined. The merger has impacted positively on chemical industries. In Construction and Engineering industries liquidity, efficiency, profitability performance indicators have insignificantly improved aftermerger while market prospect and leverage performance indicators have insignificantly deteriorated. The merger has mixed (negative and positive) impacts on construction and engineering industries. In Tobacco and Cigarettes industry market prospect and profitability performance indicators have insignificantly improved after- merger while liquidity, efficiency and leverage have insignificantly deteriorated. The merger has mixed (negative and positive) impacts on Tobacco and Cigarettes industry. The merger has different effects on different sub-sectors of the industry. Ismail et al. (2009) [51] studied the impact of Mergers and Acquisition transaction on the corporate financial performance of the construction and technology sectors between the period starting from 1996 till 2003. The main objectives of the study are mainly concerned with the significant improvements of corporate financial performance after the Merger and Acquisition transaction, and testing if the type of industrial sector has a direct impact on the company's financial performance. It is concluded that some corporate financial performance indicators like profitability, achieved statistically significant returns in the period after Mergers and Acquisitions, especially the construction sector. Other financial performance indicators such as liquidity, efficiency, cash flow position and solvency reflect insignificant improvements post mergers in the short-run analysis in both sectors. The study resulted that mergers in the technology sector show insignificant improvements in corporate financial performance in the short run. The results of this research contribute significantly to the Mergers and Acquisitions research in the Egyptian Market. Azevedo et al. (2016) [52] examined the industry type that is much successful post-merger. The sample was taken from more than 8000 completed merger and acquisition cases from Fifteen European Country. By measuring the post-merger performance accounting-based ratios and operating proxies, tax and financial synergies. The researcher concluded that Freight, Transport, Travel \& Storage Services are the industries with the best performance in general and the tax efficiency is the synergy with most value generation across the other types of synergies. It is also concluded that in financial synergies, was the Property Services sector and in the revenue-enhancement synergies and in tax synergies the Construction sector was the industry with more synergistic value creation.

\section{Research Methodology \& Design}

The theoretical framework, research design and the empirical study are all prepared and reviewed based on previous literature. This theoretical framework describes the 
direct relations between the different study variables, independent, control and dependent variables. The independent variable is the acquisition transaction which represents the event study variable. The dependent variable is the company's financial performance which will be affected by the acquisition transaction. This dependent variable for further clarification and facilitation will be explained by four of financial ratios which are liquidity, profitability, activity \& capital structure ratios. Figure 1 describes the theoretical framework:

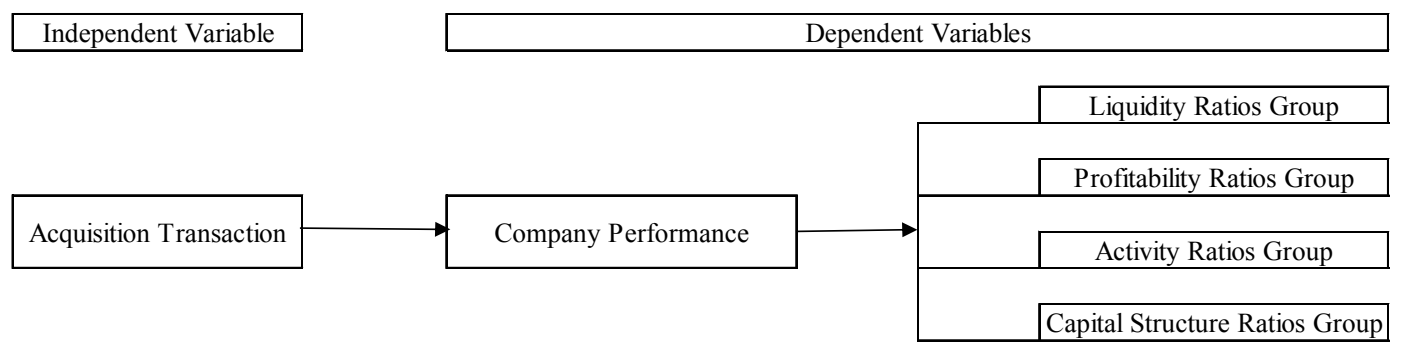

Figure 1. Theoretical Framework.

After discussing the first part of the design, the second and the third part of this framework explain the impact of specific industrial sub-sector on the company performance (Part 2), and the impact of company size (measured by issued capital) on the company performance (Part 3). Both parts are represented in Figure 2 with addition of control variables, which are company size and industrial sub-sector.

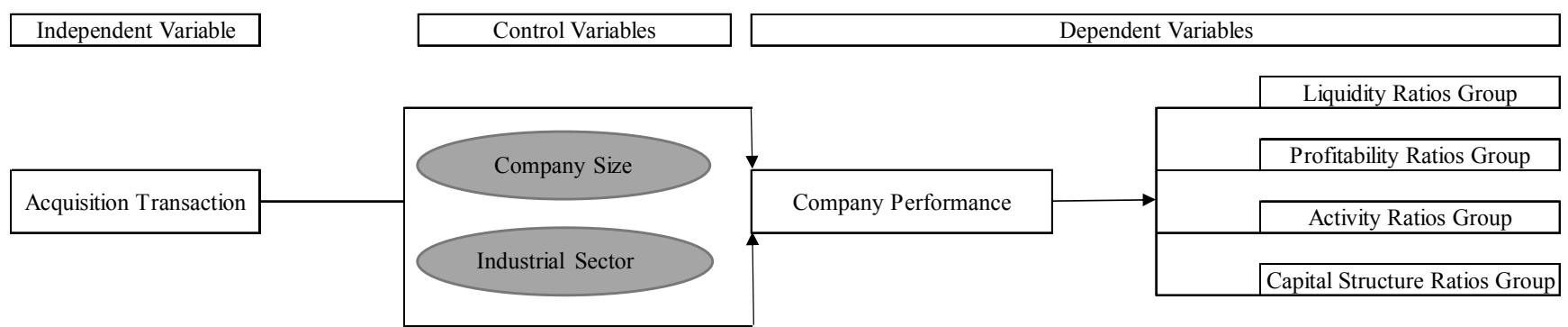

Figure 2. Theoretical Framework.

Table 1 represents and describes the dependent, independent and control variables.

Table 1. Research Variables Brief Description.

\begin{tabular}{lll}
\hline Variable & Type & Brief Description \\
\hline Acquisition Transaction & Independent & Acquire majority of ownership in a target company \\
Company Performance & Dependent & Change in the company performance after the acquisition transaction \\
Liquidity Ratios Group & Dependent & Ratios that are used to measure the company's ability to pay its short-term debts. \\
Profitability Ratios Group & Dependent & Ratios that assess business's ability to generate earnings relative to it associated expenses \\
Activity Ratios Group & Dependent & Ratios measure firm's ability to convert different accounts within its balance sheets into cash or sales \\
Capital Structure Group & Dependent & Ratios show how firm finances its overall operations and growth by using different sources of funds. \\
Company Size & Control & Variable shows how company size affects the company performance after the acquisition transaction \\
Industrial Sector & Control & Variable shows how company being belonging to certain industrial subsector affect the company \\
\end{tabular}

Source: The data developed here by the researcher according to previous literature.

Table 2 represents these ratios, the financial ratios, measurement of each ratio and the assumed relationships.

Table 2. Ratios Analysis with Their Measurements.

\begin{tabular}{|c|c|c|c|}
\hline Ratios Analysis Group & Ratios & Measurements & $\begin{array}{l}\text { Assumed } \\
\text { Relationship }\end{array}$ \\
\hline \multirow{3}{*}{ Liquidity Analysis Ratios } & Current ratio & $\begin{array}{l}\text { Current Assets/ } \\
\text { Current Liabilities }\end{array}$ & Percentage Increase/Decrease \\
\hline & Quick Ratio & $\begin{array}{l}\text { (Current Assets-Inventories)/Current } \\
\text { Liabilities }\end{array}$ & Percentage Increase/Decrease \\
\hline & Net Working Capital to Total Asset Ratio & $\begin{array}{l}\text { (Current Assets-Current } \\
\text { Liability)/Total Assets }\end{array}$ & Percentage Increase/Decrease \\
\hline \multirow[b]{2}{*}{ Profitability Analysis Ratios } & Return on Assets (ROA) & Net Income/Average Total Assets & Percentage Increase/Decrease \\
\hline & Return on Equity (ROE) & $\begin{array}{l}\text { Net Income/Average Shareholders' } \\
\text { Equity }\end{array}$ & Percentage Increase/Decrease \\
\hline
\end{tabular}




\begin{tabular}{|c|c|c|c|}
\hline Ratios Analysis Group & Ratios & Measurements & $\begin{array}{l}\text { Assumed } \\
\text { Relationship } \\
\end{array}$ \\
\hline \multirow{11}{*}{ Activity Analysis Ratios } & $\begin{array}{l}\text { Return on Common Stock } \\
\text { (ROCE) }\end{array}$ & Net Income/Average common Stocks & Percentage Increase/Decrease \\
\hline & Gross Profit Margin & Gross Profit/Sales & Percentage Increase/Decrease \\
\hline & Net Profit Margin & Net Income / Sales & Percentage Increase/Decrease \\
\hline & Earning Per Share (EPS) & Net Income/Number of common shares & Percentage Increase/Decrease \\
\hline & Basic Earning Power (BEP) & $\begin{array}{l}\text { Earning before Interest \&tax/Total } \\
\text { Average Assets }\end{array}$ & Percentage Increase/Decrease \\
\hline & Return on Investments (ROI) & Net Income / Average Investments & Percentage Increase/Decrease \\
\hline & Assets Turnover & Net Sales/Average Total Assets & $\begin{array}{l}\text { Times Increase/ } \\
\text { Decrease }\end{array}$ \\
\hline & Net Fixed Assets Turnover & Net Sales/Average Net Fixed Assets & Times Increase/Decrease \\
\hline & Inventory Turnover & Sales cost /Average Inventory & Times Increase/Decrease \\
\hline & Account Receivables Turnover & Net Sales/Average Receivables & Times Increase/Decrease \\
\hline & Days Sales Outstanding (DSO) & 360/Account Receivables Turnover & Days Increase/Decrease \\
\hline \multirow{2}{*}{ Capital Structure Analysis Ratios } & Debt to Equity & Total Liabilities /Total Shareholders & Percentage Increase/Decrease \\
\hline & Debt to Assets & Total Liabilities/Average assets & Percentage Increase/Decrease \\
\hline
\end{tabular}

Source: The data developed here by the researcher according to previous literature.

There is no separate sector as industrial. This research is mainly concerned with the Industrial Companies during the period of the study. For simplicity and the research objective, the industrial companies in the Egyptian Stock Exchange under has been divided into four Sub industrial sectors:

a. Basic Resources and Utilities Sub-sector.

b. Construction and Materials Sub-sector.

c. Personal and Household Products Sub-sector.

d. Food, Beverages and Pharmaceutical Sub-sector.

Company Size:

a. Companies with issued capital below 50 M EGP (small and medium sizes)

b. Companies with issued capital above 50 M EGP (large size)

\subsection{Hypotheses Formulation \& Testing}

The study hypotheses are:

H1: There is a Significant Difference between the performance of the acquired companies before and after the acquisition.

For testing purposes and for simplicity, The Researcher breaks down the main hypothesis into four sub-hypotheses

H1.1: There is a Significant Difference in Liquidity of the acquired companies before and after the acquisition.

H1.2: There is a Significant Difference in Profitability of the acquired companies before and after the acquisition.

H1.3: There is a Significant Difference in Activity of the acquired companies before and after the acquisition.

H1.4: There is a Significant Difference in Capital Structure of the acquired companies before and after the acquisition.

$\mathrm{H} 2$ : Industry sub-sector has an impact on the postperformance of the acquired companies.

H3: Capital issued has an impact on the- post-performance of the acquired companies.

\subsection{The Event Study Methodology}

An event study is a Research Methodology to assess the impact of an event on the value of a firm. This part describes how far event study is related to the acquisition process.
Sitthipongpanich (2011) [53] described the event study as an empirical analysis normally used for the measurement of the event effect on stocks' prices and returns. Some studies test the volume of stock trading, and volatility of return, but the majority of previous literature examine the stock price changes. The main use of event study is to evaluate the effect of the company's strategic and restructuring policies over its value. The event study is being used in different study areas, such as finance, accounting, marketing, management, information technology, economics and law.

\subsection{The Research Test}

By using Mann-Whitney Test, the period before the event could be easily compared with the period after the event and test the Significant Difference between performances of the acquired companies. The Ranks table provides information regarding the output of the actual Mann-Whitney U test. It shows mean rank and sum of ranks for the two groups tested. Mean rank is a method of handling data with the same observed frequency occurring at two or more consecutive ranks, by assigning the average of the ranks as the rank for the common frequency, for example if we have the following observations, 3.5, 2.7. 2.1, 5.3 and 2.1 then the ranking will be as follows $4,3,1,5$ and 1 respectively. The sum of ranks is 14 and the mean rank is 2.8 . The average number of observations is known by their ranking and it could be compared easily after and before the event according to the observations. Each year before the event and after the event will be tested separately by all the selected financial ratios, then a mean for the period before and after will be compared to each other. The study main formula is: mean of T-3, T-2, $\mathrm{T}-3$ will be compared to the mean of $\mathrm{T}+3, \mathrm{~T}+2, \mathrm{~T}+3$, where $\mathrm{T}$ is the year of the acquisition. and +- signs refer to the year either before (- sign) or after (+sign) the acquisition transaction.

\subsection{Sampling and Data Collection}

This study will focus on the acquisition transactions between years 2003-2015 within the listed industrial 
companies in Egypt Stock Exchange. As seen in appendices $\mathrm{A}$ and $\mathrm{B}$, during this period about 125 acquisition transaction in the stock exchange in addition to 13 mergers. Out of these transactions there are 31 industrial companies. The researcher uses secondary sources to collect the required data (financial statements and annual reports). The data of the sample are mainly collected from:

a. The Stock Exchange in Egypt reports and website.

b. Companies regular published reports.

c. Misr for Central Clearing, Depositary and Registry (MCDR).

d. Other Authorized Private and Public Organizations.

\section{Results of the Analysis}

The part provides results of the descriptive and statistical analysis and their interpretation. The results of analysis will be presented to match the framework of the research hypothesizes, starting by the whole sample testing results, then by the sub-sectors testing results, finally the company size testing results. All tables in this part are derived by using (SPSS) to express the sample means, mean ranks, standard deviations and the asymptotic Significance (Asymp. Sig. 2taled for z-statistic) or par value of the Mann Whitney test.

\subsection{Testing the Whole Sample}

Table 3. Whole Sample Results for The Four Groups of Ratios.

\begin{tabular}{|c|c|c|c|c|c|c|c|}
\hline \multicolumn{8}{|c|}{ Average Means, Means Rank and Standard Deviations for The Ratios Groups Ratios for the Sample } \\
\hline & \multicolumn{2}{|c|}{ Means } & \multicolumn{2}{|c|}{ Mean Rank } & \multirow{2}{*}{$\begin{array}{l}\text { Asymp. Sig. } \\
\text {.(2-tailed) for z-statistic }\end{array}$} & \multicolumn{2}{|c|}{ ST. Dev. } \\
\hline & Pre- & Post- & Pre- & Post- & & Pre- & Post- \\
\hline Liquidity Analysis Ratios & 116.1 & 141.1 & 41.9 & 43.4 & $77.5 \%$ & 112.0 & 197.2 \\
\hline Profitability Analysis Ratios & 39.5 & 28.8 & 48.5 & 34.1 & $0.8 \%$ & 42.2 & 47.6 \\
\hline Activity Analysis Ratios & -0.6 & 0.01 & 41.8 & 43.5 & $76.1 \%$ & 21.8 & 18.8 \\
\hline Capital Structure Analysis Ratios & 0.9 & 1.1 & 38.8 & 47.7 & $10.0 \%$ & 0.8 & 0.6 \\
\hline
\end{tabular}

Source: Data collected by the researcher. Financial Ratios Analysis Numbers are calculated by Factor Analysis Tools.

As mentioned before, Factor analysis is a statistical tool used to describe variability among observed, correlated variables regarding a potentially lower number of unobserved variables called factors. In table 3 by using the factor analysis tools and specially the component score coefficient matrix that unified the financial ratios into groups and convert these ratios to be one number for each group and check this number before and after the event by taking confidence intervals of $90 \%$ and $95 \%$ for the $\mathrm{z}$ statistics to express how these ratios groups affected by the event of acquisition. And whether the hypothesis will be accepted or rejected. Next part the researcher will discuss each group and how the acquisition event will impact each analysis group after the transaction. The first group of financial ratios is the liquidity ratios, as shown in table 3 , the liquidity ratios was 116.1 before the event then after the event it has been changed to be 141.1 that indicates that the liquidity ratios have increased but at the same time by taking $95 \%$ confidence interval the $\mathrm{z}$ statistic for the group is $77.5 \%$ that means it is insignificant. That means that Hypothesis number H1.1 will be rejected. H1.1: There is a Significant Difference between Liquidity performance of the acquired companies before and after the acquisition. Second group of financial ratios is the profitability ratios, as shown in table 3 , the profitability financial analysis ratio was 39.5 before the event then after the event it has been changed to be 28.8 that indicates that the profitability analysis ratios have decreased and at the same time by taking $90 \%$ confidence interval the $\mathrm{z}$-statistic for the group is $0.8 \%$ that means it is significant, that means that Hypothesis number H1.2 will be accepted. H1.2: There is a Significant Difference between Profitability performance of the acquired companies before and after the acquisition. Third group of financial ratios is the activity analysis ratios, as shown in table 3 , that the activity analysis ratio was -0.6 before the event then after the event it has been changed to be 0.01 that indicates that the profitability analysis ratios have increased, but by taking $95 \%$ confidence interval the $\mathrm{z}$ statistic for the group is $76.1 \%$ that means that Hypothesis number H1.3 will be rejected. H1.3: There is a Significant Difference between Activity performance of the acquired companies before and after the acquisition. Forth group of financial ratios is the capital structure ratios, as shown in table 3, that the capital structure ratio was 0.9 before the event then after the event it has been changed to be 1.1, that indicates that the capital structure analysis ratios have increased, by taking $90 \%$ confidence interval the $\mathrm{z}$ statistic for the group is $10 \%$ that means that Hypothesis number H1.4 will be accepted. H1.4: There is a Significant Difference between Capital Structure performance of the acquired companies before and after the acquisition. The standard deviations for the groups that the numbers before and after the event are so near that mean they seem to be at the same distance from their means after and before the event except in the liquidity ratios which appears to be doubled after the event.

\subsection{Testing the Sample Sub-sectors Ratio Analysis}

Now by testing the sub-sectors by the financial ratios analysis. Previously known that there are four financial ratios, liquidity, profitability, financial activity and capital structure ratios as shown in tables 4 and 5 . 
Table 4. Sample Ratios Results for Basic Resources and Utilities and Constructions and Materials Sub-sectors.

\begin{tabular}{|c|c|c|c|c|c|c|c|}
\hline \multicolumn{8}{|c|}{ Average Means and Standard Deviations for The Ratios Groups By Sub-sector } \\
\hline & \multicolumn{7}{|c|}{ Basic Resources and Utilities Sector } \\
\hline & \multicolumn{2}{|c|}{ Means } & \multicolumn{2}{|c|}{ Mean Rank } & \multirow{2}{*}{$\begin{array}{l}\text { Asymp. Sig. } \\
\text { (2-tailed) for z-statistic }\end{array}$} & \multicolumn{2}{|c|}{ ST. Dev. } \\
\hline & Pre- & Post- & Pre- & Post- & & Pre- & Post- \\
\hline Liquidity Analysis Ratios & 103.9 & 174.2 & 9.4 & 14.4 & $7.4 \%$ & 55.5 & 115.5 \\
\hline Profitability Analysis Ratios & 31.7 & 15.8 & 15.1 & 9.2 & $3.6 \%$ & 20.3 & 13.6 \\
\hline Activity Analysis Ratios & 3.0 & 4.8 & 12.4 & 11.7 & $80.6 \%$ & 44.5 & 30.3 \\
\hline Capital Structure Analysis Ratios & 1.4 & 0.6 & 15.9 & 8.5 & $0.9 \%$ & 1.3 & 0.3 \\
\hline
\end{tabular}

Table 4. Continue.

\begin{tabular}{|c|c|c|c|c|c|c|c|}
\hline & \multicolumn{7}{|c|}{ Average Means and Standard Deviations for The Ratios Groups By Sub-sector } \\
\hline & \multicolumn{7}{|c|}{ Construction and Materials Sector } \\
\hline & Means & & Meal & & $\begin{array}{l}\text { Asymp. Sig. } \\
\text {.(2-tailed) for z-statistic }\end{array}$ & ST. Dev. & \\
\hline Liquidity Analysis Ratios & $\begin{array}{l}\text { Pre- } \\
83.8\end{array}$ & $\begin{array}{l}\text { Post- } \\
76.2\end{array}$ & $\begin{array}{l}\text { Pre- } \\
15.1\end{array}$ & $\begin{array}{l}\text { Post- } \\
13.6\end{array}$ & $65.5 \%$ & $\begin{array}{l}\text { Pre- } \\
47.3\end{array}$ & $\begin{array}{l}\text { Post- } \\
50.3\end{array}$ \\
\hline Profitability Analysis Ratios & 52.8 & 48.3 & 15.2 & 13.4 & $55.7 \%$ & 68.1 & 82.5 \\
\hline Activity Analysis Ratios & -1.1 & 1.0 & 13.1 & 16.6 & $26.9 \%$ & 5.6 & 6.7 \\
\hline
\end{tabular}

Source: Data collected by the researcher. Financial Ratios Analysis Numbers are calculated by Factor Analysis Tools.

Table 5. Sample Ratios Results for Personal and Household Products and Food, Beverages and Pharmaceutical Sub-sectors.

\begin{tabular}{|c|c|c|c|c|c|c|c|}
\hline \multicolumn{8}{|c|}{ Average Means and Standard Deviations for The Ratios Groups By Sub-sector } \\
\hline & \multicolumn{7}{|c|}{ Personal and Household Products Sector } \\
\hline & \multicolumn{2}{|c|}{ Means } & \multicolumn{2}{|c|}{ Mean Rank } & \multirow{2}{*}{$\begin{array}{l}\text { Asymp. Sig. } \\
\text { (2-tailed) for z-statistic }\end{array}$} & \multicolumn{2}{|c|}{ ST. Dev. } \\
\hline & Pre- & Post- & Pre- & Post- & & Pre- & Post- \\
\hline Liquidity Analysis Ratios & 89.1 & 86.5 & 6.4 & 5.3 & $57.1 \%$ & 16.72 & 24.5 \\
\hline Profitability Analysis Ratios & 32.4 & 20.4 & 7.3 & 3.8 & $8.9 \%$ & 13.96 & 3.8 \\
\hline Activity Analysis Ratios & -6.0 & 10.9 & 6.6 & 5.0 & $45.0 \%$ & 10.31 & 3.1 \\
\hline Capital Structure Analysis Ratios & 0.9 & 1.0 & 5.9 & 6.3 & $85.0 \%$ & 0.24 & 0.5 \\
\hline
\end{tabular}

Table 5. Continue.

\begin{tabular}{|c|c|c|c|c|c|c|c|}
\hline & \multicolumn{7}{|c|}{ Average Means and Standard Deviations for The Ratios Groups By Sub-sector } \\
\hline & \multicolumn{7}{|c|}{ Food, Beverages and Pharmaceutical Sector } \\
\hline & Means & & Mea & & $\begin{array}{l}\text { Asymp. Sig. } \\
\text {.(2-tailed) for z-statistic }\end{array}$ & ST. Dev. & \\
\hline Liquidity Analysis Ratios & $\begin{array}{l}\text { Pre- } \\
178.4\end{array}$ & $\begin{array}{l}\text { Post- } \\
208.0\end{array}$ & $\begin{array}{l}\text { Pre- } \\
12.5\end{array}$ & $\begin{array}{l}\text { Post- } \\
9.8\end{array}$ & $33.9 \%$ & $\begin{array}{l}\text { Pre- } \\
187.2\end{array}$ & $\begin{array}{l}\text { Post- } \\
385.8\end{array}$ \\
\hline Profitability Analysis Ratios & 33.1 & 25.8 & 13.2 & 8.5 & $10.1 \%$ & 10.5 & 6.4 \\
\hline Activity Analysis Ratios & -0.2 & -3.1 & 11.9 & 10.9 & $73.3 \%$ & 10.7 & 9.6 \\
\hline
\end{tabular}

Source: Data collected by the researcher. Financial Ratios Analysis Numbers are calculated by Factor Analysis Tools.

Table 4 shows diversified performance for both subsectors in the four groups of ratios. Basic Resources liquidity ratios increased from 104 to 174 with a significant $\mathrm{z}$-statistic $7.4 \%$ by taking a confidence interval of $90 \%$. When looking to the profitability ratios, there is a decrease from 32 to 16 with a $3.6 \%$ significant $\mathrm{z}$-statistic. Activity analysis ratios increased from 3 to 4.8 with an insignificant $\mathrm{z}$-statistic of $81 \%$. The last ratios are the capital structure that decreased from 1.4 to 0.6 with $0.9 \%$ significant $\mathrm{z}$-statistic by taking $95 \%$ confidence interval. In the Construction and Materials sub-sector, liquidity ratios decreased from 84 to 76 with an insignificant $\mathrm{z}$-statistic $66 \%$ by taking a confidence interval of $95 \%$ or $90 \%$. Profitability ratios has a decrease from 52.8 to 48.3 with a $55.7 \%$ insignificant $\mathrm{z}$-statistic. Activity analysis ratios increased from -1 to 1 with an insignificant $z-$ statistic of $27 \%$. The last group of ratios is the capital structure that increased from 0.8 to 1.4 with $0.2 \%$ significant z-statistic by taking $95 \%$ confidence interval. In the Personal and Household Products Sub-Sector, liquidity ratios decreased from 89.1 to 86.5 with an insignificant $\mathrm{z}$-statistic $57 \%$ by taking a confidence interval of $95 \%$. Profitability ratios decreased from 32.4 to 20.4 with $8.9 \%$ significant $\mathrm{z}$ statistic with confidence interval of $90 \%$. Activity analysis ratios decreased from -6 to -11 with an insignificant $z$ statistic of $45 \%$. The last group of ratios is the capital structure that increased from 0.9 to 1 with $85 \%$ insignificant z-statistic by taking $95 \%$ or $90 \%$ confidence intervals. In the Food, Beverages and Pharmaceutical sub-sector, liquidity ratios increased from 178 to 208 with an insignificant zstatistic $44 \%$ by taking a confidence interval of $95 \%$. Profitability ratios decreased from 33 to 26 with a $10.1 \%$ insignificant $\mathrm{z}$-statistic with a confidence interval of $90 \%$. 
Activity analysis ratios increased from -0.2 to -3.1 with an insignificant z-statistic of $73 \%$. The last group of ratios is the capital structure that increased from 0.71 to 1.3 with $0.8 \%$ significant z-statistic by taking a $90 \%$ confidence interval.

Hypothesis H2: Industry sub-sector has an impact on the post-performance of the acquired companies. This hypothesis will be accepted for some ratios and rejected for others, for Basic Resources and Utilities Sub-sector, liquidity, profitability and capital structure ratios will be accepted and financial activity ratios will be rejected. For Construction and Materials Sub-sector liquidity, profitability and financial activity ratios will be rejected, and capital structure ratios will be accepted. By testing Personal and Household Products Sub-sector profitability ratios will be accepted and liquidity, financial activity and capital structure ratios will be rejected. Food, Beverages and Pharmaceutical Subsector liquidity, profitability and financial activity ratios will be rejected and capital structure ratios will be accepted. By taking into consideration that all groups of ratios are tested by taking confidence intervals of $95 \%$ or $90 \%$.

\subsection{Testing the Sample Ratio Analysis by Issued Capital}

Now the researcher is testing the companies above and below $50 \mathrm{M}$ issued capital by the financial analysis. Table 6 discusses the financial analysis by the four main groups for the companies with issued capital below the $50 \mathrm{M}$.

Table 6. Sample Results by Groups of Ratios for Companies Below 50 M Issued Capital.

\begin{tabular}{|c|c|c|c|c|c|c|c|}
\hline \multicolumn{8}{|c|}{ Average Means and Standard Deviations for The Ratios Groups By Capital } \\
\hline & \multicolumn{7}{|c|}{ Capital Below $50 \mathrm{M}$} \\
\hline & \multicolumn{2}{|c|}{ Means } & \multicolumn{2}{|c|}{ Mean Rank } & \multirow{2}{*}{$\begin{array}{l}\text { Asymp. Sig. } \\
\text {.(2-tailed) for z-statistic }\end{array}$} & \multicolumn{2}{|c|}{ ST. Dev. } \\
\hline & Pre- & Post- & Pre- & Post- & & Pre- & Post- \\
\hline Liquidity Analysis Ratios & 95.5 & 75.2 & 19.0 & 15.4 & $29.4 \%$ & 47.9 & 39.1 \\
\hline Profitability Analysis Ratios & 29.5 & 23.6 & 19.5 & 14.6 & $16.2 \%$ & 16.6 & 26.9 \\
\hline Activity Analysis Ratios & -3.9 & -2.6 & 16.7 & 18.7 & $55.2 \%$ & 6.7 & 7.9 \\
\hline Capital Structure Analysis Ratios & 0.8 & 1.3 & 13.9 & 22.7 & $1.1 \%$ & 0.4 & 0.7 \\
\hline
\end{tabular}

Source: Data collected by the researcher. Financial Ratios Analysis Numbers are calculated by Factor Analysis Tools.

liquidity ratios decreased from 95.5 to 75.2 with an insignificant z-statistic $29.4 \%$ by taking a confidence interval of $95 \%$. When testing profitability ratios, it decreased from 29.5 to 23.6 with a $16.2 \%$ insignificant z-statistic. Activity analysis ratios increases from -3.9 to -2.6 with an insignificant $z$-statistic of $55.2 \%$. The last group of ratios is the capital structure that increased from 0.8 to 1.3 with $1.1 \%$ significant z-statistic by taking $95 \%$ confidence interval. Table 7 discussed the financial analysis by the four main groups of ratios for the companies with issued capital above the $50 \mathrm{M}$.

Table 7. Sample Results by Groups of Ratios for Companies Above 50 M Issued Capital.

\begin{tabular}{|c|c|c|c|c|c|c|c|}
\hline \multicolumn{8}{|c|}{ Average Means and Standard Deviations for The Ratios Groups By Capital } \\
\hline & \multicolumn{7}{|c|}{ Capital Above $50 \mathrm{M}$} \\
\hline & \multicolumn{2}{|c|}{ Means } & \multicolumn{2}{|c|}{ Mean Rank } & \multirow{2}{*}{$\begin{array}{l}\text { Asymp. Sig. } \\
\text { (2-tailed) for z-statistic }\end{array}$} & \multicolumn{2}{|c|}{ ST. Dev. } \\
\hline & Pre- & Post- & Pre- & Post- & & Pre- & Post- \\
\hline Liquidity Analysis Ratios & 130.3 & 185.1 & 23.5 & 28.3 & $25.0 \%$ & 139.5 & 245.1 \\
\hline Profitability Analysis Ratios & 46.4 & 32.3 & 29.6 & 19.9 & $2.0 \%$ & 52.4 & 57.9 \\
\hline Activity Analysis Ratios & 1.6 & 1.7 & 25.5 & 25.5 & $99.2 \%$ & 27.8 & 23.6 \\
\hline Capital Structure Analysis Ratios & 0.9 & 0.9 & 25.2 & 26.0 & $85.2 \%$ & 0.9 & 0.5 \\
\hline
\end{tabular}

Source: Data collected by the researcher. Financial Ratios Analysis Numbers are calculated by Factor Analysis Tools.

Liquidity ratios increases from 130.3 to 185.1 with an insignificant $\mathrm{z}$-statistic $25 \%$ by taking a confidence interval of $95 \%$ or $90 \%$. When testing profitability ratios, it decreased from 46.4 to 32.3 with a $2 \%$ significant $z$-statistic by using confidence interval $95 \%$. Activity analysis ratios increased from 1.6 to 1.7 with an insignificant $\mathrm{z}$-statistic of $99.2 \%$. The last ratios group of ratios is the capital structure remained the same 0.9 with $85.2 \%$ an insignificant $\mathrm{z}$ statistic by taking $95 \%$ or $90 \%$ confidence interval. The hypothesis that is related to this sub-sector is H3 that states: H3: Capital issued has an impact on the- post-performance of the acquired companies. This hypothesis will be accepted for some groups of ratios and rejected for others. Capital structure ratios for the companies with issued capital below $50 \mathrm{M}$ will be accepted with $\mathrm{z}$-statistic of $1.1 \%$ and profitability ratios for companies issued capital above $50 \mathrm{M}$ will be also accepted with $2 \%$ z-statistic. On the other hand, all other ratios will be rejected either for companies with issued capital below $50 \mathrm{M}$ or above $50 \mathrm{M}$ by taking confidence interval $90 \%$ and $95 \%$.

\section{Conclusion, Recommendations}

In this study, the researcher tests three hypotheses concerning the impact of acquisition transaction on the acquired company post-performance for the whole sample, sub-sectors and issued capital and comparing these results with the literature review deals with the same subject. By testing the whole sample, the researcher reached the following final results, there is an insignificant difference in the liquidity performance before and after the acquisition, by taking either $95 \%$ or $90 \%$ confidence intervals, the $z$ - 
statistic for the group is $78 \%$. There is a significant difference in the profitability performance before and after the acquisition, by taking a $95 \%$ confidence interval the $\mathrm{z}$ statistic for the group is $0.8 \%$, but it is a negative change. There is an insignificant difference in the activity performance before and after the acquisition, by taking either $95 \%$ or $90 \%$ confidence intervals the z-statistic for the group is $76 \%$. There is a significant difference in the capital structure analysis performance before and after the acquisition, by taking $90 \%$ confidence interval the $\mathrm{z}$ statistic for the group is $10 \%$, a significant increase in capital structure. By testing the impact of sub-sectors on post-performance of acquired company, the researcher reached the following final results. Basic Resources liquidity ratios group increases from 104 to 174 with a significant $\mathrm{z}$-statistic $7 \%$ by taking a confidence interval of $90 \%$. When looking to profitability ratios group, there is a decrease from 32 to 16 with a $3.6 \%$ significant $z$-statistic. Activity analysis ratios group increases from 3 to 5 with an insignificant $\mathrm{z}$-statistic of $81 \%$. The last ratios group is the capital structure that decreases from 1.4 to 0.6 with $1 \%$ significant $\mathrm{z}$-statistic by taking $95 \%$ confidence interval. Construction and Materials sub-sector liquidity ratios group decreases from 84 to 76 with an insignificant z-statistic $66 \%$ by taking a confidence interval of $95 \%$ or $90 \%$. Profitability ratios group has a decrease from 52.8 to 48.3 with a $55.7 \%$ insignificant $\mathrm{z}$-statistic. Activity analysis ratios group increases from -1 to 1 with an insignificant $z-$ statistic of $26.9 \%$. The last ratios group is the capital structure that increases from 0.8 to 1.4 with $0.2 \%$ significant z-statistic by taking $95 \%$ confidence interval. Personal and Household Products liquidity ratios group decreases from 89 to 87 with an insignificant $z$-statistic $57 \%$ by taking a confidence interval of $95 \%$. Profitability ratios group there is decreased from 32 to 20 with $9 \%$ significant $\mathrm{z}$-statistic with a confidence interval of $90 \%$. Activity analysis ratios group decreases from -6 to -11 with an insignificant z- statistic of $45 \%$. The last ratios group is the capital structure that increases from 0.9 to 1 with $85 \%$ insignificant $z$-statistic by taking $95 \%$ confidence interval. Food, Beverages and Pharmaceutical sub-sector liquidity ratios group increases from 178 to 208 with an insignificant z-statistic $34 \%$ by taking a confidence interval of $95 \%$. Profitability ratios group there is a decrease from 33 to 26 with a $10.1 \%$ insignificant $\mathrm{z}$-statistic with a confidence interval of $90 \%$. Activity analysis ratios group decreases from -0.2 to -3 with an insignificant $z$-statistic of $73 \%$. The last ratios group is the capital structure that increases from 0.7 to 1.3 with $0.8 \%$ significant $\mathrm{z}$-statistic by taking $95 \%$ confidence interval. There are different findings for the group financial ratios for the four sub-sectors. By testing the impact of company size on post-performance of acquired company, the researcher reached the following final results. For the first group that includes the companies that have issued capital below $50 \mathrm{M}$, liquidity ratios group decreases from 96 to 75 with an insignificant z-statistic $29 \%$ by taking a confidence interval of $95 \%$. When testing profitability ratios group, it decreases from 30 to 24 with a $16.2 \%$ insignificant $\mathrm{z}$-statistic. Activity analysis ratios group increases from -3.9 to -2.6 with an insignificant $z$ statistic of $55 \%$. The last ratios group, the capital structure group increases from 0.8 to 1.3 with $1.1 \%$ significant $\mathrm{z}$ statistic by taking $95 \%$ confidence interval.

On the other hand, for the second group that includes companies with issued capital above $50 \mathrm{M}$, liquidity ratios group increases from 130 to 185 with an insignificant $\mathrm{z}$ statistic $25 \%$ by taking a confidence interval of $95 \%$ or $90 \%$. When testing profitability ratios group, there is a decrease from 46 to 32 with $2 \%$ significant $\mathrm{z}$-statistic by using a confidence interval of $95 \%$. Activity analysis ratios group increases from 1.6 to 1.7 with an insignificant z-statistic of $99 \%$. The last ratios group that the capital structure remains the same 1 with $85 \%$ an insignificant $z$-statistic by taking $95 \%$ or $90 \%$ confidence interval.

For Hypothesis H1, the final result is to accept H1.2 and H1.4 that show the significant difference in profitability and capital structure ratios of the acquired companies before and after acquisition. On the other hand, to reject H1.1 and $\mathrm{H} 1.3$ that show the insignificant difference in liquidity and activity ratios of the acquired companies before and after acquisition. For Hypothesis H2: the final result is to accept the significant difference of the acquired companies before and after acquisition in the liquidity, profitability and capital structure ratios for the Basic Resources and Utilities Sub-Sector, capital structure ratios for Construction and Materials Sub-Sector, profitability ratios for Personal and Household Products Sub-Sector, capital structure ratios for Food, Beverages and Pharmaceutical Sub-Sector. On the other hand, the final result is to reject the significance of the rest of ratios. For Hypothesis H3: the final result is to accept the significant difference of the acquired companies before and after acquisition for capital structure ratios for companies issued capital below $50 \mathrm{M}$ and profitability ratios for companies issued capital above $50 \mathrm{M}$. On the other hand, the final result is to reject significance of the rest of ratios.

\section{Future Research}

After completing this research, the researcher recommends that this study could be done again but for a different period instead of taking the period from 2003 to 2015, another period may be considered between years 2011 and 2018 after the Egyptian Revolution in 2011 by all its consequences on the Egyptian Economy. Another study recommendation is to study the same subject but for other sectors in the Egyptian Market like the commercial or service sectors and test the effect of acquisition events on the acquired companies for these sectors. The final suggestion is to study the same subject but for the unlisted companies to know the impact of acquisition events on those companies for unquoted companies. 


\section{References}

[1] Roberts, A., Wallace, W. \& Moles, P. (2016). Mergers and Acquisitions. Heriot-Watt University, MQ-A2-engb 1/2016 (1020). www.ebsglobal.net

[2] Robinson, S. \& Zerdin, M. (2013). The Mergers \& Acquisitions Review, Seventh Edition. Law Business Research Ltd. www.thelawreviews.co.uk

[3] Metwalli A. M. \& Tang, R. Y. W. (2003). Merger and Acquisition Activity in the Middle East and a Four-Country Composition. International Journal of Commerce and Management, Vol. 13, No. 1, 81-102. https://doi.org/10.1108/eb047461

[4] Martin, S. (2007). Mergers: An Overview. Krannert Faculty, Purdue University. https://krannert.purdue.edu/faculty/

[5] Hitt, M. A. \& Pisano, V. (2003). The Cross-Border Merger and Acquisition Strategy: Research Perspective. The Journal of the Iberoamerican Academy of Management, Vol. pp. 133 144. DOI: $10.1108 / 15365430380000522$.

[6] Chen, H. K., Li, C. A \& Pan, K. M. (2004). A Theory of Mergers and Acquisitions: Synergy, Private Benefits, or Hubris Hypothesis. http://gebrc.nccu.edu.tw/GEBRC/

[7] Ismail, T. H., Abdou, A. A., \& Annis, R. M., (2011). Review of Literature Linking Corporate Performance to Mergers and Acquisitions. The Review of Financial and Accounting Studies, Issue 1 (2011).

[8] Bouwman, C., Fuller, K. \& Nain, A. (2004). The Performance of Stock Price Driven Acquisitions. Review of Financial Studies, Vol. 22, No. 2, 2009.

[9] Bradley, M. \& Sundaram, A. (2006). Acquisitions and Performance: A Re-Assessment of the Evidence. www.ssrn.com.

[10] Rani, N., Yadav, S. S. \& Jain, P. K. (2014). Impact of Corporate Governance Score on Abnormal Returns and Financial Performance of Mergers and Acquisitions. Procedia Economics and Finance, Volume 5, 2013, Pages 637-646. DOI 10.1007/s40622-014-0067-8.

[11] Harrison, J. S., Hart, M. \& Oler, D. K. (2013). Leverage and acquisition performance. Springer Science Journal, (2014) 43: 571-603. DOI 10.1007/s11156-013-0385-5.

[12] Al-hroot, Y. (2016). The Impact of Mergers on Financial Performance of the Jordanian Industrial Sector. International Journal of Management \& Business Studies, Vol. 6, Issue 1, Jan - March 2016. DOI: 10.13140/RG.2.1.4480.3602.

[13] Moctar, N. B. \& Xiaofang, C. (2014). The Impact of Mergers and Acquisition on The Financial Performance of West African Banks: A Case Study of Some Selected Commercial Banks. International Journal of Education and Research, Vol. 2 No. 1 January 2014.

[14] Rathinam, I. B. \& Sridharan, P. S. (2016). Post-Mergers and Acquisitions Performance of Select Indian Banks. IUP Journal of Bank Management, Vol. 15 Issue 1, p 17-27. 11p.

[15] Rashid, A. \& Naeem, N. (2016). Effects of Mergers on Corporate Performance: An Empirical Evaluation Using OLS and The Empirical Bayesian Methods. www.sciencedirect.com

[16] Abdulwahab, B. \& Ganguli, S. (2017). The Impact ok Mergers and Acquisitions on Financial Performance of Banks in Bahrain. ResearchGate Professional Network. https://www.researchgate.net/publication/318653846

[17] Abbas, Q., Hunjra, A. I., Azam, R., Ijaz, M. S. \& Zahid, M. (2014). Financial performance of banks in Pakistan after Merger and Acquisition. Journal of Global Entrepreneurship Research 4 (1), 13.

[18] Jallow, M. S., Masazing, M. \& Basit, A. (2017). The Effects of Mergers \& Acquisitions on Financial Performance: Case Study of UK Companies. International Journal of Accounting \& Business Management, Vol. 5 (No.1), April, 2017. DOI: 24924/ijabm/2017.04/v5.iss1/74.92

[19] Mulwa, J. M. \& Mwangi, M. (2015). The Effect of Mergers and Acquisitions on The Financial Performance of Oil Firms in Kenya. Master Degree. http://erepository.uonbi.ac.ke/

[20] Masud, N. (2015). Impact of Merger and Acquisition on Financial Performance of Banks: Evidence from Pakistan. Research Journal of Recent Sciences, Vol. 4 (5), 108-113, May (2015).

[21] Abdulazeez, D. A., Suleiman, O. and Yahaya, A. (2016). Impact of Merger and Acquisitions on the Financial Performance of Deposit Money Banks in Nigeria. Arabian Journal of Business and Management Review, 6 (4), 1-5. DOI: 10.4172/2223-5833.100021.

[22] Dutescu, A., Ponorica, A. G., \& Stanila, G. O. (2013). Effects of Mergers and Acquisitions on Financial Performance of The Target Company. Challenges of the Knowledge Society Journal. www.ftms.edu.my/journals/

[23] Reda, M. (2013). The Effect of Mergers and Acquisitions on Bank Efficiency: Evidence from Bank Consolidation in Egypt. https://erf.org.eg

[24] Olson, G. T \& Pagano, M. S. (2003). The Long-Term Impact of Bank Mergers on Sustainable Growth and Shareholder Return. Journal of Business Finance \& Accounting, 32 (9) \& (10), Nov./Dec. 2005.

[25] Ferrer, R. C. (2012). An Empirical Investigation of the Effects of Merger and Acquisition on Firms' Profitability. Academy of Accounting and Financial Studies Journal, Volume 16, Number 3, 2012.

[26] Teodora, P. D. \& Braşoveanu, L. O. (2016). The Effects of Merger and Acquisitions Processes on Companies' Performance. Financial and stock exchange managementDAFI. www.dafi.ase.ro

[27] Juma, B. \& Musimenta, D. (2017). The Impact of Merger and Acquisition on Firm Performance in East Africa. Makerere Business Journal. Vol. 13, Issue 2 2017pp 109-127.

[28] Alhayek, M. A. (2018). The Effect of Acquisition on Income Statement Items in Acquired Company (Subsidiary Company)-Case Study. International Journal of Economics and Finance, Vol. 10, No. 5; 2018. https://doi.org/10.5539/ijef.v10n5p173

[29] Badreldin, A \& Kalhoefer, C. (2009). The Effect of Mergers and Acquisitions on Bank Performance in Egypt. Journal of management Technology, 25, 1-15. 
[30] Verma, N \& Sharma, R. (2014). Impact of Mergers \& Acquisitions on Firms' Long-Term Performance: A Pre-\& Post Analysis of the Indian Telecom Industry. International Journal of Research in Management \& Technology, Vol. 4, No. 1, February 2014.

[31] Sujud, H. \& Hachem, B. (2018). Effect of Mergers and Acquisitions on Performance of Lebanese Banks. International Research Journal of Finance and Economics, Issue 166 March, 2018.

[32] Singh, K. B. (2013). The impact of Mergers and Acquisitions on Corporate Financial Performance in India. Indian Journal of Research in Management, Business and Social Sciences (IJRMBSS), Vol. 1 I Issue 2 I July. 2013.

[33] Lakstutiene, A., Stankeviciene, J., Norvaisiene, R. \& Narbutiene, J. (2015). The Impact of Acquisitions on Corporate Performance Results during the Period of Economic Slowdown: Case of Lithuania. Procedia - Social and Behavioral Sciences, 213 (2015) 455 - 460.

[34] Lipeikyte, A. \& Schneider, C. (2015). How Do Mergers and Acquisitions Affect Performance of the Target Firms, The Evidence from the Baltic States. Master thesis. http://studenttheses.cbs.dk/

[35] Singh, S. \& Das, S. (2018). Impact of Post-Merger and Acquisition Activities on The Financial Performance of Banks: A Study of Indian Private Sector and Public Sector Banks. Revista Espacios Magazine, Vol. 39 (Number 26) Year 2018 • Page 25 .

[36] Kenkel, P., Gilbert, A. \& Spence, B. (2017). Post-Merger Financial Performance of Oklahoma Cooperatives. https://www.researchgate.net/publication/242189344

[37] Bayyurt, N. \& Akın, A. (2014). Effects of Foreign Acquisitions on the Performance of Securities Firms: Evidence from Turkey. Procedia - Social and Behavioral Sciences, Vol. 150, 156-161.

[38] Pervan, M., Visic, J. \& Barnjak, B. (2014). The Impact of M\&A on Company Performance: Evidence from Croatia. Procedia Economics and Finance, 23 (2015), Pages1451 1456.

[39] Nelson, R. L. (1959). Merger Movements in American Industry, 1895-1956. Princeton University Press. http://www.nber.org/books/nels59-1

[40] Gruici, B. C., Contstantin, L. G. \& Iamandi, I. E. (2010). Empirical Evidence on The Relationship Between Mergers \& Acquisitions and The Romanian Stock Market. https://www.researchgate.net/publication/49615411

[41] Liargovas, P. \& Repousis, S. (2011). The Impact of Mergers and Acquisitions on the Performance of the Greek Banking Sector: An Event Study Approach. International Journal of Economics and Finance, Vol. 3, No. 2; May 2011. Doi: 10.5539/ijef.v3n2p89.
[42] Pham, L. H. (2014). An Analysis of Pre and Post- Acquisition Financial Performance of Target Czech Banks: A Comparative Analysis. Journal of Eastern European And Central Asian Research, Vol 1, No 2 (2014). http://dx.doi.org/10.15549/jeecar.v1i2.60

[43] Bhutta, R. M., Saad, M.\& Tariq, T. A. (2015). Impact of Merger or Acquisition on Financial Performance of Firm: A Case Study of Pakistan Telecommunication Limited (PTCL). International Journal of African and Asian Studies, Vol. 13, 2015.

[44] Ntuli, M. G. (2017). An evaluation of bank acquisition using an accounting-based measure: a case of Amalgamated Bank.

[45] Joash, G. O. \& Njangiru, M. J. (2015). The Effect of Mergers and Acquisitions on Financial Performance of Banks, A Survey of Commercial Banks in Kenya. International Journal of Innovative Research and Development, Vol 4 Issue 8, 2015.

[46] Arlinda, Achsani, N. A., \& Saptono, I. T. (2015). Impact of Merger and Acquisition on Financial Performance and Financial Distress: Empirical Evidence from Indonesian Telecommunication Industry. European Journal of Business and Management, Vol.7, No.25, 2015.

[47] Larasati, N. D., Agustina, Y., Istanti, L. N. \& Wijijayanti, T. (2017). Do Merger and Acquisition Affect on Company's Financial Performance? Sriwijaya International Journal of Dynamic Economics and Business, Vol 1 (4), 2017.

[48] Filipovic, D. (2012). Impact of Company's Size on Takeover Success. Ekonomska istraživanja Journal, Vol. 25 (2012) No. 2 (435-444).

[49] Savovic, S. (2016). The Post-Acquisition Performance of Acquired Companies: Evidence from The Republic of Serbia. Economic Annals Journal, Volume LXI, No. 209 / April June 2016. DOI: 10.2298/EKA1609079S.

[50] Al-hroot, Y. (2016). The Impact of Mergers on Financial Performance of the Jordanian Industrial Sector. International Journal of Management \& Business Studies, Vol. 6, Issue 1, Jan - March 2016. DOI: 10.13140/RG.2.1.4480.3602.

[51] Ismail, T. H., Abdou, A. A., \& Annis, R. M., (2009). Exploring Improvements of Post-Merger Corporate Performance: The Case of Egypt. https://www.researchgate.net

[52] Azevedo, A. C. C., Alves, P. \& Santos, C. (2016). Industry Differences in Mergers and Acquisitions M\&A Performance and Synergies Assessment. (Doctoral dissertation) https://repositorio.ucp.pt/

[53] Sitthipongpanich, T. (2011). Understanding the Event Study. Journal of Business Administration., Vol. 34 No. 130 April June 2011. 